\title{
Pravoslavlje pred suvremenim ekološkim izazovima s posebnim naglaskom na ekumenski dijalog s Katoličkom Crkvom
}

\author{
Antun JAPUNDŽIĆ ${ }^{*}$ - ANA JELIČÍ́ ${ }^{* *}$ \\ - https://doi.org/ 10.31823/d.29.4.5 • \\ UDK: 271:502/504*272 • Pregledni članak \\ Primljeno: 22. ožujka 2021. • Prihvaćeno: 20. prosinca 2021.
}

Sažetak: Iako pravoslavna teologija ima dugu i bogatu tradiciju, u njezinoj daljoj povijesti nije zabilježen značajniji interes za ekološku problematiku. Naime ekološku zauzetost nalazimo u promišljanjima nekolicine pravoslavnih filozofa i teologa tek posljednjih nekoliko desetljeća. Njihova nastojanja temelje se na teologiji stvaranja, asketskoj praksi i bogatoj istočnoj liturgiji. U pravoslavnoj teologiji posebno mjesto zauzima Ioannis Zizioulas, dok je nemali doprinos i Amvrosija Ermakova te Elizabeth Theokritoff $i$ drugih. Ipak, zamah u sirenju ekološko-teološkoga horizonta radi suzbijanja daljnjih ekoloških ugroza i problema dogodio se, u novije vrijeme, i zbog dijaloške otvorenosti ekumenskoga patrijarha Bartolomeja i pape Franje, koji su u ekologiji prepoznali velik izazov za ekumenizam.

** Doc. dr. sc. Ana Jeličić, Sveučilišni odjel za forenzične znanosti,

Sveučilište u Splitu, Ruđera Boškovića 33, 21000 Split, Hrvatska, anjelici08@gmail.com

Ključne riječi: ekologija, pravoslavna teologija, teologija stvaranja, asketizam, ekološka kriza, ekumenizam.

\section{Uvod}

Suvremeni čovjek ujedno je uzročnik i žrtva globalne ekološke i socijalne krize. Uništavanje prirodnih dobara predstavlja opasnost i za sadašnju generaciju čovječanstva i za buduće naraštaje. ${ }^{1}$ Stoga je nedvojbena čovjekova odgovornost za prirodni ambijent i briga za prirodna dobra koja ima na raspolaganju.

${ }^{1}$ Usp. K. LEŚNIEWSKI, Ecumenical Patriarch Bartholomew's »Green message « to the World, u: Roczniki Teologii Ekumenicznej 58(2011.)3, 33-34. 
Zasigurno da je ekologija danas vrlo aktualna tema. Njoj se uglavnom pristupa interdisciplinarno i to najčešće sa sociološkoga, političkoga, ekonomskoga, antropološkoga, ali i mnogih drugih stajališta. U našem radu nastojat ćemo se osvrnuti na povezanost teologije i ekologije, i to posebice iz perspektive pravoslavnih teologa. Iznijet ćemo njihova stajališta prema ekologiji i očuvanju stvorenoga. Naime suvremena teologija stvaranja i stvorenja bavi se dvama pitanjima, odnosom između teologije i prirodne znanosti te ekologijom. ${ }^{2}$

Mnogobrojni suvremeni kršćanski autori povezuju ekologiju i teologiju te govore o ekologiji u religioznom kontekstu. ${ }^{3}$ Kada je riječ o teološkom kontekstu i govoru o ekologiji, onda je uočljiva činjenica da se o ekologiji govori pod različitim vidovima, u biblijsko-teološkom kontekstu, ${ }^{4} \mathrm{u}$ eshatološkoj perspektivi, ${ }^{5} \mathrm{u}$ ekumenskom kontekstu ${ }^{6}$ itd. $U$ tom smislu i naše razmatranje obuhvaća različita, ali ujedno i srodna promišljanja pojedinih suvremenih pravoslavnih teologa koji se u okviru svoga znanstvenoga interesa bave ekološkom problematikom i zauzetošću za očuvanje stvorenoga.

\section{Biblijsko-teološka pozadina očuvanja okoliša}

Diskurs vezan uz ekologiju, u teološkim krugovima, veže se uz teologiju stvaranja kojoj je polazište teološki nauk i kršćanska vjera prema kojima je svijet stvorio Bog. Bog je onaj koji stvara svijet i koji ga prožima, ali isti taj svijet sa sobom nosi određena ograničenja i opasnosti kada je riječ o stvorenoj prirodi. ${ }^{7}$ Uzmemo li u obzir činjenicu i tvrdnju koja kaže: »Teološki se pitanje okoliša povezuje s teologijom stvorenja $\ll^{8}$, stoga ne možemo govoriti o okolišu i baviti se pitanjima okoliša, a da

\footnotetext{
${ }^{2}$ Usp. P. C. PHAN, Stvaranje/stvorenje, u: Suvremena katolička enciklopedija, Split, 1998., 919.

${ }^{3}$ Usp. npr. Ž. BEZIĆ, Kršćanin i ekologija, u: Crkva u svijetu 25(1990.)1, 47-58.; P. G. GIANAZZA, Temi di teologia orientale 2, Bologna, 2012., 41-43.; S. MORANDINI, Teologija i ekologija, Zagreb, 2013., 5-205.; V. POZAIĆ, Ekologija u teologiji. Dominium Terrae - Amor Terrae, u: ISTI (ur.), Ekologija: znanstveno-etičko-teološki upiti i obzori, Zagreb, ${ }^{22004 ., ~ 155-175 . ; ~ L . ~ T O M A S ̌ E V I C ́, ~ E k o-~}$ logija: izazov kršćanstvu, u: Socijalna Ekologija: časopis za ekološku misao i sociologijska istraživanja okoline 9(2000.)1-2, 23-33.

${ }^{4}$ Usp. P. VIDOVIĆ, Svijet - čovjekov dom i Božji hram. Ekologija na početku Biblije, u: V. POZAIĆ (ur.), Ekologija: znanstveno-etičko-teološki upiti i obzori, 133-153.

${ }^{5}$ Usp. P. C. PHAN, Escatology and ecology: The Environment in the End-Time, u: Irish Theological Quarterly 62(1996.), 3-16.

${ }^{6}$ Usp. A. JAPUNDŽIĆ, Ekumenizam i ekologija, u: Diacovensia 25(2017.)1, 5-7.; A. J. KELLY, Ecumenism of ecology, u: Pacifica 28(2015.)2, 160-175.

${ }^{7}$ Usp. I. ZIZIOULAS, Il creato come eucaristia. Approccio teologico al problema dell'ecologia, Magnano, 1994., 27-45.

${ }^{8}$ D. CARROLL, Ekologija/okoliš, u: Suvremena katolička enciklopedija, 241.
} 
pri tome ne dotaknemo teologiju stvorenja i ne osvrnemo se na nju..$^{9}$ Stoga se ponajprije želimo osvrnuti na biblijsko-teološke temelje na kojima se gradi govor o očuvanju stvorenoga.

\section{ODgovornOST ZA OČUVANJE ZEMLJE}

U izvještaju iz Knjige Postanka, koji se pripisuje svećeničkoj predaji (usp. Post 1), nalazimo opis stvaranja svijeta, a kao vrhunac Božjega stvaranja jest čovjek koji je stvoren na sliku Božju (usp. Post 1,26-27). Čovjeku, koji je kruna stvaranja, Bog je povjerio da gospodari zemljom i svim onim što je stvorio (usp. Post 1, 26. 28-30). Najstariji izvještaj Knjige Postanka (usp. Post 2, 4-25) izvještava nas, među osta$\mathrm{lim}$, i o odgovornosti koju Bog daje čovjeku u odnosu prema svemu stvorenom. U tome kontekstu Knjiga Postanka kaže: »Bog, uzme čovjeka i postavi ga u edenski vrt da ga obrađuje i čuva « (Post 2, 15). Dakle već je tada Bog povjerio čovjeku brigu i odgovornost za sve stvoreno. Međutim potrebno je ovdje naglasiti da čovjek nije apsolutni vladar ni apsolutni gospodar zemlje, nego tek Božji suradnik na zemlji. ${ }^{10} \gg$ Osim toga, valja istaknuti da se, prema biblijskoj objavi, čovjekova nadmoć u odnosu na niža stvorenja nikad ne smije pretvoriti u distanciranje, nezainteresiranost ili čak prezir prema drugim bićima. Položaj čovjeka prema svemu stvorenome sličan je položaju vrtlara, koji 'obrađuje i čuva' vrt, a ne 'pljačka ga i ne pustoši' «. ${ }^{11}$ Čovjeku je stvoreni svijet povjeren, ali ne da ga nerazborito iskorištava, već da upravlja njime i da ono što je stvoreno bude na korist i na dobro čovjeku. Upravo čovjekova zadaća, u skladu s tim, jest osvrnuti se i promisliti o svom odnosu prema ambijentu u kojem živi, a isto tako razmotriti svoj odnos prema svemu stvorenom. On je dužan čuvati prirodna dobra i brinuti za ono što je Bog stvorio i što bi trebalo biti na službu čovjeku. Budući da je čovjek stvoren na sliku Božju, njegov odnos prema stvorenom svijetu ujedno se može iščitati i kao odnos prema Bogu.

Brigom za očuvanje stvorenoga na poseban način bavi se ekologija, a kao što je već poznato, pojam ekologija dolazi od grčkih riječi olkos (kuća, dom, boravište) i $\lambda o ́ \gamma o \varsigma$ (riječ, govor; znanost), što bi značilo 'govor o okolišu. ${ }^{12} \mathrm{~S}$ druge pak strane sam sadržaj ekologije kao znanosti na poseban se način štiti i produbljuje posljed-

${ }^{9}$ Usp. E. THEOKRITOFF, Living in God's Creation. Orthodox perspectives on ecology, Crestwood, New York, 2009.

${ }^{10}$ Usp. Đ. PARDON, Zemlja: dar kušnja i zadaća. Biblijska teologija zemlje u Knjizi Postanka 1 - 11, Zagreb, 2014., 89-97.; G. M. SALVATI, Ekologija, u: Enciklopedijski teološki rječnik, Zagreb, 2009., 252-254., ovdje 252.

${ }^{11}$ G. M. SALVATI, Ekologija, 253.

${ }^{12}$ Usp. Ecologia, u: H. CARRIER, Dizionario della cultura. Per un'analisi culturale e l'inculturazione, Città del Vaticano, 1997., 148-150.; G. M. SALVATI, Ekologija, 252. 
njih desetljeća. ${ }^{13}$ Budući da ekologija proučava i na poseban se način zanima za odnos čovjeka prema okolišu i ambijentu u kojem čovjek živi, kao takva je »postala predmetom pozornosti teologije onda kad se, osobito na Zapadu, izoštrio osjećaj prema problemu okoliša $\ll .{ }^{14}$ Stoviše, može se također uočiti da »ekološki problem, iako se predstavlja kao problem znanosti i u stupnju visoke etike, odgoja i državnih propisa, također je i teološki problem $\ll{ }^{15} \mathrm{Za}$ mnoge pravoslavne autore teološka refleksija o ekološkim problemima ima okosnicu upravo u teologiji stvaranja. ${ }^{16}$

\section{Ekologija u pravoslavnoj teologiji}

Budući da »ekološka teologija ima živ osjećaj zajedništva zemlje i svijeta kao Božjeg stvorenja $\ll{ }^{17}$, mnogi će teolozi u svojim teološko-ekološkim promišljanjima polaziti upravo od teologije stvaranja, odnosno od onoga stvorenoga, ali i od čovjekova odnosa prema stvorenomu.

Tako pravoslavna teologinja Elizabeth Theokritoff razvija takozvanu »etiku stvaranja «. »'Etika stvaranja' zapravo nije nešto o čemu pravoslavni mnogo govore $\mathrm{i}$ teško je znati što reći o tome argumentu. $\ll{ }^{18}$ Međutim svakako je nužno i važno pratiti i sam razvoj interesa za to područje kako bi se moglo uočiti zanimanje za očuvanje prirode i svega stvorenoga. Tako Theokritoff kroz svoju »etiku stvaranja « razlučuje tri relevantne faze kod pravoslavnih teologa kada je riječ o ekološkoteološkim nastojanjima.

Prva faza obuhvaća razdoblje šezdesetih i sedamdesetih godina prošloga stoljeća unutar pravoslavne teologije. U tom razdoblju budi se teološki interes za sve stvoreno, kao i za samo stvaranje, a samim time onda i za ekologiju. Taj prvotni ekološki zanos širili su Olivier Clément, Dumitru Staniloae, Pavel Evdokimov i drugi. Bio je to svojevrsni početak ekoteologije. ${ }^{19}$

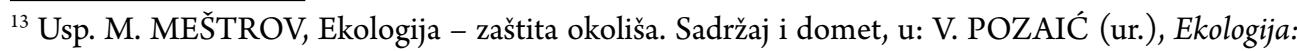
znanstveno-etičko-teološki upiti i obzori, 17-20.

${ }^{14}$ G. M. SALVATI, Ekologija, 252.

${ }^{15}$ I. ZIZIOULAS, Il creato come eucaristia, 27.

${ }^{16}$ A. ERMAKOV, La Chiesa ortodossa e i problemi dell'ecologia, u: L. A. VALVA, L. CREMASCHI, A. MAINARDI (prir.), L'uomo custode del creato. Atti del XX Convegno ecumenico internazionale di spiritualità ortodossa, Bose, 5-8 settembre 2012., Magnano, 2013., 81.

${ }^{17}$ R. GIBELLINI, Kratka povijest teologije XX. stoljeća, Zagreb, 2016., 137.

${ }^{18}$ E. THEOKRITOFF, L'etica della creazione nella teologia ortodossa contemporanea, u: L. A. VALVA, L. CREMASCHI, A. MAINARDI (prir.), L'uomo custode del creato, 371.

${ }^{19}$ Usp. isto, 372. 
U drugo razdoblje spadaju teološki spisi koji datiraju iz osamdesetih godina dvadesetoga stoljeća koji upozoravaju na posebne aspekte i traže odgovore na krizna pitanja okoliša. ${ }^{20}$

Treća i ujedno posljednja faza bila bi od devedesetih godina pa nadalje. U toj fazi može se uočiti da se devedesetih godina među pravoslavnima javlja »povjerenje u povratak originalnim načelima istočne kršćanske kozmologije $\ll^{21} \mathrm{i}$ u tom kontekstu teologija stvaranja ostaje osjetljiva na suvremene ekoteološke rasprave. ${ }^{22}$ Ovdje dolazi do izražaja i ono što smo istaknuli na početku, da pravoslavni teolozi na poseban način u svojim promišljanjima pridaju važnost tradiciji.

U toj, posljednjoj fazi razvoja ekološke misli i zabrinutosti za probleme u okolišu posebno se istaknuo grčki pravoslavni teolog Ioannis Zizioulas, koji se ujedno smatra vodećim predstavnikom toga razdoblja.

\section{IOANNIS ZIZIOULAS O EKOLOŠKIM PROBLEMIMA}

Ioannis Zizioulas smatra kako pitanja ekološke naravi spadaju među najznačajnije izazove i pitanja suvremenoga čovjeka za treće tisućljeće. Konkretno, vjeruje kako je ekološka problematika »najozbiljniji problem okrenut čovječanstvu danas $\ll{ }^{23}$ jer ugrožavanje okoliša i ambijenta narušava cjelovitost i izvornost same prirode.

Tako se može detektirati kako je suvremena kultura snažno obilježena tehnikom te znanstvenim i tehnološkim napretkom, ${ }^{24}$ zbog čega je izgubljen osjećaj za ono što je sveto, a sveto je ono što je nepovrjedivo, očuvano i dostojno dubokoga poštovanja. ${ }^{25}$ Stoga, zbog nedostatka i gubitka štovanja svetosti prirode u današnje vrijeme javlja se i ekološka kriza. Zizioulas ju vidi kao »jedinstvenost koja je globalni problem $\ll,{ }^{26}$ koji obuhvaća čitavo čovječanstvo i ljude u cjelini. ${ }^{27} \mathrm{Za}$ ekološku krizu nema jednostavnoga rješenja, ali svi ljudi snose određenu odgovornost

${ }^{20}$ Usp. isto, $372-373$.

${ }^{21}$ Isto, 373.

${ }^{22}$ Usp. isto, 373.

${ }^{23}$ J. ZIZIOULAS, The Orthodox Church and the Third Millennium, u: G. EDWARDS (prir.), The One and the Many. Studies on God, Man, the Church, and the World Today, Alhambra, 2010., 388401., ovdje 399.

${ }^{24}$ Usp. R. FISICHELLA, Kultura, u: Enciklopedijski teološki rječnik, 571-572.

${ }^{25}$ Usp. R. GERARDI, Svet (sanctum/sacrum), u: Enciklopedijski teološki rječnik, 1123.

${ }^{26}$ I. ZIZIOULAS, Il creato come eucaristia, 5.

${ }^{27}$ Pravoslavne Crkve zauzimaju se za ekologiju upravo zbog toga što je stvaranje nešto što je sveto. Bog koji sve stvara jest svet te je, dosljedno tomu, i samo stvaranje sveto, a čovjek kao najuzvišenije stvorenje pozvan je brinuti se o onome što je stvoreno. Stoga odgovornost za taj globalni problem snose svi, bez iznimke, pa onda, naravno, i teolozi. 
za nastanak ekološke krize. Zbog toga ni Zizioulas ne daje tek jednostavno recept ili pak rješenje za ekološku krizu. Međutim on otvara teološki horizont u kojem čovjek postaje svjestan svoje odgovornosti jer je, zapravo, ekološka kriza povezana $s$ antropološkom krizom i na neki način ovisi o njoj. Grčki teolog ovdje vidi važnu ulogu i zadaću kršćana, čija se odgovornost treba očitovati u očuvanju stvorenoga te smatra da bi kršćani mogli mnogo toga dati kada je riječ o očuvanju stvorenoga. $\mathrm{U}$ tom smislu bilo bi potrebno dati više pozornosti na primjer propovijedanju o ekologiji, katehiziranju i slično. ${ }^{28}$

Prema tom grčkom teologu, postoje dva bitna razloga zbog kojih se Pravoslavna Crkva zauzima za ekologiju. Prvi je razlog strogo teološki i povezan je s pravoslavnom kozmologijom i antropologijom, dok je drugi pastoralni te je povezan sa svijetom u kojem pravoslavni žive u relaciji s drugim ljudskim bićima i njihovim prirodnim ambijentom (okolišem). ${ }^{29}$

Promatrajući u teološkom i liturgijskom kontekstu, Zizioulas je uvjerenja da je najvažniji »liturgijski etos «. Naime pravoslavna tradicija duboko je liturgijska i upravo liturgijski život daje posebnu viziju i pogled na čovjeka i svijet. U liturgijskoj viziji svijeta ne postoji samo naravno i nadnaravno, nego postoji prirodno i stvoreno kao realnost koja proizlazi od Boga i biva opet prinesena Bogu. Upravo to se zbiva u euharistiji u kojoj se stvorenje uzdiže Bogu i zahvaljuje i u kojoj se susreću povijest i vječnost. Stoga je euharistija, među ostalim, spomen zahvalnosti na stvorenome te čovjek kao eshatološko stvorenje u euharistiji uzdiže hvalu Bogu i zahvaljuje na primljenim darovima. Budući da euharistija ima eshatološku dimenziju i usmjerena je prema eshatonu, ona daje svijetu eshatološku stvarnost, ali isto tako ulazi u povijest, i to preko euharistijske zajednice. ${ }^{30}$

Važno je stoga više isticati i promovirati posebno »euharistijski etos $\ll$ u kojem na poseban način dolazi do izražaja aktivna čovjekova uloga i zadaća. Slijedom toga, čovjeku je dakle Bog povjerio odgovornost za stvoreno. Čovjek jest stvorenje, ali isto tako preuzima dio stvaranja u svoje ruke i snosi odgovornost za stvaranje. ${ }^{31} \mathrm{U}$ tom smislu Zizioulas ističe da je čovjek pozvan biti »svećenik stvaranja «i on upravo u toj ulozi vidi poslanje čovjeka. ${ }^{32}$ Biti $\gg$ svećenik stvaranja « ovdje se ne odnosi

${ }^{28}$ Usp. I. ZIZIOULAS, Sacerdoti della creazione: il servizio del patriarcato ecumenico per la protezione del creato, u: L. A. VALVA, L. CREMASCHI, A. MAINARDI (prir.), L'uomo custode del creato, $76-77$.

${ }^{29}$ Usp. isto, 67.

${ }^{30}$ Usp. I. ZIZIOULAS, Il creato come eucaristia, 71-88.

${ }^{31}$ Usp. E. THEOKRITOFF, Green Patriarch, Green Patristics: Reclaiming the Deep Ecology of Christian Tradition, u: Religions 116(2017.)8, 1-19., ovdje 9-10.

${ }^{32}$ Usp. I. ZIZIOULAS, Sacerdoti della creazione, 76-77. 
samo na zaređene službenike, nego tu ulogu i zadaću Bog daje svima. Svijet je dar, ali to je ujedno i zadaća čovjeka da se brine za razvoj same prirode. Imati svećeničku dužnost znači imati brigu i ljubav prema stvorenomu, a čovjek je pozvan živjeti svoju svećeničku ulogu prema svijetu, što može jedino u Kristu. Upravo euharistijski darovi jesu plodovi čovjekova rada i njegove aktivnosti u stvaranju, a kroz zahvaljivanje i prinošenje darova Bogu očituje se i povezanost stvorenja s Bogom. ${ }^{33}$ Stoga ta paradigma euharistije i čovjekove »svećeničke uloge « upozorava na odnos stvorenja prema Bogu Stvoritelju i na odgovornost koju čovjek ima prema stvorenomu. ${ }^{34}$

\section{Kršćanska odgovornost za zajednički dom}

Uvidjevši da je ekološka kriza problem koji obuhvaća suvremeno čovječanstvo i čovjeka u suvremenom svijetu, može se reći da »kršćanstvo dijeli mnogo odgovornosti za ekološku krizu. To su svi prepoznali «. ${ }^{35}$ Tako na primjer i poznati talijanski teolog Rossino Gibellini vidi da $\gg$ rješenje ekoloških problema nije samo problem osobne etike (mikroetika) nego i društvene etike (makroetika); ona se mora konkretizirati u orijentaciji ekonomskog rasta u smjeru društvene pravednosti i ekološke podnošljivosti, u pobijanju zagađivanja i upropaštavanja okoliša, u odgovornom postupanju prema izvorima privrede (resursi) i prema energiji, te $u$ prikladnoj organizaciji krajolika $\ll{ }^{36} \mathrm{Na}$ tom putu prepoznavanja odgovornosti za ekološku krizu uočavamo dakle brojne kršćanske teologe koji svojim doprinosom nastoje dati određene smjernice za prevladavanje ekološke krize.

\subsection{TeOlOŠKe SMJERNICE U BORBI S NAJVEĆIM EKOLOŠKIM PROBLEMIMA}

Promišljanja dvojice pravoslavnih teologa mogu poslužiti kao orijentacija u pogledu ekoloških nastojanja. Episkop Gatčina te rektor petrogradske teološke akademije i sjemeništa Amvrosij Ermakov kaže: »Stvorenje je naša kuća, mi smo stvoreni u harmoniji s njom $\ll^{37}$, dok aktualni ekumenski carigradski patrijarh Bartolomej tvrdi: »Okoliš je kuća koja prima ljudsko biće «. ${ }^{38}$ Ako je tomu tako, onda je upravo čovjek taj koji snosi odgovornost za tu kuću, odnosno za ambijent u kojem živi.

\footnotetext{
${ }^{33}$ Usp. E. THEOKRITOFF, Green Patriarch, Green Patristics, 9.; I. ZIZIOULAS, Il creato come eucaristia, 62-70.

${ }^{34}$ Usp. E. THEOKRITOFF, Green Patriarch, Green Patristics, 3-5.

${ }^{35}$ J. ZIZIOULAS, The Orthodox Church and the Third Millennium, 399.

${ }^{36}$ R. GIBELLINI, Kratka povijest teologije XX. stoljeća, 137.

${ }^{37}$ A. ERMAKOV, La Chiesa ortodossa e i problemi dell'ecologia, 87.

${ }^{38}$ BARTOLOMEO, Una casa chiamata terra, Milano, 2016., 64.
} 
Međutim trenutačna društveno-kulturna, u jednoj mjeri čak i duhovna situacija upozorava na to da je suvremeni čovjek malo osviješten po pitanju vlastite odgovornosti za okoliš i ambijent. U njegovu ponašanju prema prirodi zrcale se egoizam i utilitarizam. ${ }^{39}$ Stoga Ermakov smatra kako prevladavanje ekološke krize nužno treba pretpostaviti nadvladavanje te egoistične vizije u odnosu čovjeka i prirode, iz koje se generira ekološka kriza. ${ }^{40}$

$\mathrm{S}$ druge strane ekumenski patrijarh Bartolomej, osim što dijagnosticira probleme u odnosu čovjeka i prirode, sugerira dva puta ili načina kako se konkretno taj odnos može poboljšati. To su liturgijski i asketski put.

Pod pojmom askeza opravdano možemo očekivati određeno odricanje, odnosno redukciju potrošnje u suvremenom konzumerističkom društvu. Međutim u ovom kontekstu askeza nije tek ograničavanje, odricanje od materijalnoga svijeta. Dapače, prakticiranje askeze značilo bi da se na stvoreni svijet gleda s osobitim poštovanjem te da se ne gleda isključivo i samo na korisnost stvorenoga. Upravo asketizam trebao bi u tom smislu voditi prema manjoj i racionalnijoj uporabi prirodnih resursa. $S$ tim u vezi pravoslavni teolozi u asketskoj tradiciji vide potencijal kvalitetnijega ekološkoga življenja u kojem asketska tradicija daje novu perspektivu samoograničenja u sustavu održivoga života. ${ }^{41}$ To i sam aktualni ekumenski carigradski patrijarh izražava na sljedeći način: »Mi vjerujemo da po našem jedinstvenom liturgijskom $i$ asketskom etosu duhovno učenje Pravoslavne Crkve može pružiti važan teoretski i deontološki smjer za brigu o našem planetu Zemlji «. ${ }^{42}$

Promatrajući u teološkom konte kstu, Bartolomej smatra da je čovjek pozvan vratiti se na »euharistijski« $\mathrm{i} \gg$ asketski« način života, a to za njega znači dati slavu Bogu sa zahvalnošću za sve stvoreno, što je čovjeku darovano, ali i za što je on ujedno dužan skrbiti se. Iz vjerovanja da su život i svako stvorenje dar proizlazi i zahvalnost na tome daru, što se iskazuje na poseban način u liturgiji. Tako pojmovi $\gg$ euharistijski $<\mathrm{i}$ »asketski $\ll$ u ovom kontekstu trebaju biti objašnjeni i poučavani ponajprije u Crkvi. ${ }^{43}$

U konkretnom životu i djelovanju pojedinaca to bi značilo zauzeti stav strahopoštovanja i divljenja prema stvorenomu. U tom smislu Bartolomej jasno povezuje, pa i poistovjećuje dva odnosa. Naime u odnosu Crkve prema okolišu reflektira se odnos Crkve prema siromahu. Snažnu vezu između brige za okoliš i brige za čovje-

\footnotetext{
${ }^{39}$ Usp. A. ERMAKOV, La Chiesa ortodossa e i problemi dell'ecologia, 85-86.

${ }^{40}$ Usp. isto, 93-94.

${ }^{41}$ Usp. E. THEOKRITOFF, Living in God's Creation, 93-116.

${ }^{42}$ BARTHOLOMEW, Address to the Scenic Hudson, New York, November 13, 2000, u: J. CHRYSSAVGIS (ur.), On Earth as in Haeven. Ecological Vision and Initiatives of Ecumenical Patriarch Bartholomew, New York, 2012., 111-116., ovdje 111.
}

${ }^{43}$ Usp. BARTOLOMEO, Una casa chiamata terra, 37-46. 
ka Bartolomej pronalazi u Matejevu evanđelju, u prispodobi o posljednjem sudu $(\mathrm{Mt} 25,35){ }^{44}$

Napose, upravo u liturgiji pravoslavni zahvaljuju Bogu Stvoritelju na svemu stvorenome i na daru stvorenja prinoseći kruh i vino na oltar za vrijeme liturgije. U istom tom liturgijskom obredu do izražaja dolazi i sakramentalna dimenzija svijeta. >U sakramentu euharistije mi dajemo Bogu ono što je Božje: kruh i vino, preko zajednice i zajedno s cijelom zajednicom koja sebe prikazuje s poniznom zahvalnošću Stvoritelju. Preko tih darova Bog preobražava kruh i vino, tj. svijet, u misterij susreta $\ll^{45}$, precizira Bartolomej.

Ta smjernica ukorijenjena je uglavnom u teologiji stvaranja. »Pravoslavna teologija podsjeća da je važno ne izgubiti najdublju i esencijalnu viziju da razmatra svijet kao stvaranje $\ll^{46}$, odnosno kao stvorenu baštinu koja je potrebna čovjeku i sadašnjim generacijama, ali i nadolazećim. ${ }^{47}$

Među brojnim Bartolomejevim inicijativama, kada je riječ o očuvanju živoga svijeta, neizostavno je spomenuti kako je taj ekumenski patrijarh zaslužan za to što su Dan molitve za očuvanje stvorenoga prihvatile sve pravoslavne Crkve. Naime za vrijeme patrijarha Dimitrija, još od 1989. godine, Sveti Sinod proglasio je 1. rujna kao Dan molitve za očuvanje stvorenoga. Oko toga se kasnije zalagao i Dimitrijev nasljednik, patrijarh Bartolomej, čijom su zaslugom Dan molitve za očuvanje stvorenoga 1991. godine prihvatile sve pravoslavne Crkve. ${ }^{48}$ Nadalje, u Katoličkoj Crkvi papa Franjo 2015. godine službeno je proglasio Svjetski dan molitve za skrb o stvorenom svijetu koji ima i svoju ekumensku dimenziju, a obilježava se isti dan kao i u Pravoslavnoj Crkvi, tj. 1. rujna. U tom smislu Papa je prepoznao važnost zajedničke brige za stvoreno kao znak puta kojim hode svi kršćani i kao blagotvornu prigodu kojom se svjedoči rastuće zajedništvo. ${ }^{49}$

${ }^{44}$ Usp. BARTOLOMEJ, Predgovor, u: FRANJO, Naša majka zemlja. Kršćansko čitanje ekoloških izazova, Zagreb, 2020., 10-11.

${ }^{45}$ BARTOLOMEO, Una casa chiamata terra, 43.

${ }^{46}$ A. ERMAKOV, La Chiesa ortodossa e i problemi dell'ecologia, 87.

${ }^{47}$ Usp. isto, 85-86.

${ }^{48}$ Usp. J. CHRYSSAVGIS, A New Heaven and a New Earth: Orthodox Christian Insights from Theology, Spirituality and the Sacraments, u: J. CHRYSSAVGIS i dr. (ur.), Toward an Ecology of Transfiguration. Orthodox Christian Perspectives on Environment, Nature and Creation, New York, 2013., 152-162., ovdje 154.; Usp. M. GNAVI, Prefazione, u: BARTOLOMEO, Una casa chiamata terra, 17.; FRANJO, Naša majka Zemlja, 58-59.

${ }^{49}$ Usp. Lettera del Santo Padre Francesco per l'istituzione della $\gg$ Giornata mondiale di preghiera per la cura del creato $\ll\left[1^{\circ}\right.$ settembre $]$. Dostupno na: http://www.vatican.va/content/francesco/it/letters/2015/documents/papa-francesco_20150806_lettera-giornata-cura-creato.html (20.3. 2021.). 


\subsection{EKOLOŠKO PITANJE U OKRILJU EKUMENIZMA}

Ekološka svijest i ekološka odgovornost imaju u sebi ekumensku dimenziju ${ }^{50}$ koja je zaživjela, u najvećoj mjeri, zahvaljujući djelovanju dvojice crkvenih poglavara, ekumenskoga patrijarha Bartolomeja i pape Franje. Međutim i sami dokumenti Katoličke Crkve ističu važnost ekološko-ekumenske suradnje. Tako Direktorij za primjenu načela i normi o ekumenizmu jasno ističe: »Odgovornost za zaštitu okoliša, stvorenja, koje ima u sebi svoje vlastito dostojanstvo, dao je sam Stvoritelj svim narodima ukoliko su čuvari stvorenoga (...). Na različitim razinama, katolike se ohrabruje da sudjeluju u zajedničkim pothvatima za proučavanje i sučeljavanje s problemima koji ugrožavaju dostojanstvo stvorenoga i dovode u opasnost cijeli ljudski rod. $\ll^{51}$

Čini se da je upravo ta ekumenska dimenzija ekoloških nastojanja izražena i kod istočnih i kod zapadnih crkvenih poglavara, i to u nekim njihovim zajedničkim pothvatima koji su do sada postignuti. Tomu u prilog ide Četvrti simpozij o vodama koji je organiziran na inicijativu ekumenskoga patrijarha Bartolomeja, a konkretno se odnosio na Jadransko more. Taj simpozij ostao je posebno upečatljiv, među ostalim, upravo po svojoj ekumenskoj dimenziji. Naime svojevrstan plod toga simpozija bila je Deklaracija svetoga oca Ivana Pavla II. i njegove svetosti ekumenskoga patrijarha Bartolomeja potpisana 10. lipnja 2002. godine. ${ }^{52}$ To je ujedno povijesni dokument jer je riječ o prvom sporazumu o ekologiji koji je u povijesti postignut između poglavara istočne i zapadne Crkve. ${ }^{53}$ Tako papa Ivan Pavao II. i ekumenski patrijarh Bartolomej svoju zajedničku izjavu započinju sljedećim riječima: »Danas smo ovdje svi okupljeni u duhu mira, za dobro svih ljudskih bića i za zaštitu stvorenoga. U ovoj povijesnoj epohi, na početku trećega milenija, žalosni smo što svakodnevno vidimo patnje velikoga broja ljudi od nasilja, gladi, siromaš-

\footnotetext{
${ }^{50}$ Ekološka svijest, kao i ekumenska dimenzija u ekološkim nastojanjima i brizi za stvoreno, došla je do izražaja i u kontekstu Ekumenskoga vijeća crkava koje obuhvaća široko područje interesa, a među ostalim, i interes u brizi za očuvanje stvorenoga. Tako su na pojedinim generalnim skupštinama Ekumenskoga vijeća crkava došle do izražaja i ekološke teme te naglasci i smjernice u odnosu prema stvorenomu. Usp. I. MACUT, Svjetske misijske konferencije ekumenskog vijeća crkava i odnos prema stvorenome (1948. - 2013.), u: Crkva u svijetu 54(2019.)3, 413-436.

${ }^{51}$ PAPINSKO VIJEĆE ZA PROMICANJE JEDINSTVA KRŠĆANA, Direktorij za primjenu načela $i$ normi o ekumenizmu, Zagreb, 1994., br. 215.

${ }^{52}$ Usp. Firma della $\gg$ Dichiarazione di Venezia «. Dichiarazione ciongiunta del Santo Padre Giovanni Paolo II e del patriarcha ecumenico sua santità Bartolomeo I. Dostupno na: http://www.vatican. va/content/john-paul-ii/it/speeches/2002/june/documents/hf_jp-ii_spe_20020610_venicedeclaration.html (12.2.2020.).

${ }^{53}$ Usp. J. CHRYSSAVGIS, Apostolo e profeta. Vita e opere di Bartolomeo I, patriarca ecumenico di Costantinopoli, Bologna, 2018., 176.
} 
tva i bolesti. Također smo zabrinuti zbog negativnih posljedica za čovječanstvo i za sve stvoreno, što je uzrokovano degradacijom nekih osnovnih prirodnih resursa kao što su voda, zrak i zemlja, a naneseni su velikim ekonomskim i tehnološkim napretkom koji ne poznaje i ne uzima u obzir svoje granice. $\ll^{54}$

Nasljednik pape Ivana Pavla II., papa Benedikt XVI. također je bio i ekumenski i ekološki osviješten. To je dao do znanja prigodom Šestoga simpozija o vodi, koji je također organiziran na inicijativu patrijarha Bartolomeja, a kojemu je Papa priložio svoje pismo. ${ }^{55}$

Prije nego se osvrnemo na doprinose pape Franje u području ekologije, u okrilju ekumenizma važno je izdvojiti još jedan značajan ekumensko-ekološki trenutak. Naime prilikom Trećega europskoga ekumenskoga skupa, 2007. godine, pokrenuta je inicijativa prema kojoj se kroz pet tjedana slavi $\gg$ Vrijeme za stvoreno «. U okviru toga ekumenskoga projekta, od 2007. godine pa sve do danas, okupljaju se brojni vjernici, kršćani, ali i drugi, kao i oni koji sebe ne smatraju vjernicima kako bi skupa osmišljavali i provodili različite ekološke aktivnosti. ${ }^{56}$

Aktualni papa Franjo, na tragu svojih prethodnika, problematiku očuvanja okoliša prepoznaje kao ozbiljni ekumenski izazov. ${ }^{57}$ Dva su njegova krucijalna djela koja ćemo ovdje spomenuti. Na prvom mjestu neizostavna je i revolucionarna Papina enciklika Laudato si'. Bez zadiranja u detalje i analizu enciklike, o čemu je već dosta pisano, u ovom kontekstu bitno je spomenuti da svoje djelo Papa započinje citiranjem upravo ekumenskoga patrijarha Bartolomeja. Među ostalim, on kaže: »Patrijarh Bartolomej posebno je govorio o nužnosti da se svi pokajemo zbog svojega lošeg postupanja prema planetu, jer 'u mjeri u kojoj svi mi uzrokujemo male ekološke štete' pozvani smo prepoznati 'svoj, manji ili veći, doprinos izobličavanju i uništavanju okoliša'. On je više puta to odlučno i uvjerljivo potvrdio $\ll^{58}$, te nastavlja: »Bartolomej je upozorio na etičke i duhovne korijene ekoloških problema,

\footnotetext{
${ }^{54}$ Usp. Firma della $\gg$ Dichiarazione di Venezia $\ll$.

${ }^{55}$ Usp. Lettera di Sua Santità Benedeto XVI al patriarca ecumenico, Sua Santità Bartolomeo I in occasione del VI simposio su »Religion, science and the Environment « dedicato al Rio delle Amazzoni Dostupno na: http://w2.vatican.va/content/benedict-xvi/it/letters/2006/documents/hf_benxvi_let_20060706_bartolomeo-i.html (12.2.2020.).

${ }^{56}$ FRANJO, Naša majka Zemlja, 60-61.

${ }^{57}$ Papa je svoj nagovor sudionicima susreta o rudarskoj industriji u organizaciji Dikasterija za službu za cjeloviti ljudski razvoj naslovio »Čuvanje zajedničkog doma ekumenski je izazov«. Susret je upriličen 3. svibnja 2019.

${ }^{58}$ FRANJO, Laudato si'. Enciklika o brizi za zajednički dom, Zagreb, 2015., br. 8.
} 
koji nas pozivaju tražiti rješenja ne samo u tehnologiji već i u promjeni čovjeka, jer ćemo se u protivnom baviti samo simptomima. $\ll{ }^{59}$

Drugo Papino djelo na koje se želimo referirati novijega je datuma. Riječ je o djelu Naša majka Zemlja. Kršćansko čitanje ekoloških izazova.$^{60}$ Zanimljivo da je predgovor tomu djelu napisao upravo ekumenski patrijarah Bartolomej. Na tom mjestu autor se prisjetio nekoliko ključnih ekumenskih susreta i zajedničkih putovanja tijekom kojih su se ta dvojica crkvenih poglavara borila za zajedničke ciljeve, kao što su suzbijanje humanitarne krize zbog prisilnoga raseljavanja stanovništva s ratovima pogođenih teritorija i zaustavljanje vjerskih progona. U istim tim prilikama izražavali su i svoju solidarnost s onima u potrebama, zalagali su se za mir te su apelirali na zaštitu manjina, braneći njihove slobode i prava. Ono što je relevantno spomenuti jest da su u svakoj toj prigodi izražavali svoju zabrinutost i za okoliš. Bartolomej se tako prisjeća njihova boravka u Jeruzalemu 2014. godine. Tada su zajedno izjavili: »Duboko smo uvjereni da budućnost čovječanstva ovisi i o tome kako ćemo znati čuvati, mudro s ljubavlju, s pravednošću i jednakošću, dar stvorenoga što nam je Bog povjerio. $\ll{ }^{61}$ Bartolomej se, pišući predgovor novomu Papinu djelu, prisjetio još jednoga vrlo važnoga datuma za ekumensko-ekološke inicijative. Naime papa Franjo i Bartolomej sastavili su u rujnu 2017. godine, upravo na Svjetski dan molitve za skrb o stvorenom svijetu, izjavu o svetosti Božjega stvorenja i važnosti njihove zaštite od nas ljudi. ${ }^{62} \mathrm{U}$ toj poruci s posebnim naglaskom na stav solidarnosti i služenja stoji: »Naša dužnost da se odgovorno koristimo zemaljskim dobrima podrazumijeva prepoznavanje i poštovanje svih ljudi i svih živih bića. Hitan poziv i izazov da se brinemo o stvorenome svijetu poziv su čitavom čovječanstvu da radi na održivom i cjelovitom razvoju. $\ll^{63}$

Ekumenski patrijarh jasno ističe kako osim takozvanoga »ekumenizma dijaloga $\ll$ i »ekumenizma mučeništva « postoji i vrlo živi »ekumenizma okoliša « koji se te-

${ }^{59}$ Isto, br. 9.

${ }^{60} \mathrm{U}$ originalu to djelo naslovljeno je $\gg$ Nostra Madre Terra. Una lettura cristiana della sfida dell'ambiente «. Libreria Editrice Vaticana djelo je publicirala 2019., a ovdje se referiramo na hrvatsko izdanje koje je objavila Kršćanska sadašnjost, 2020.

${ }^{61}$ BARTOLOMEJ, Predgovor, 6-7.

${ }^{62}$ Usp. Messaggio congiunto di papa Francesco e del patriarca ecumenico Bartolomeo per la giornata mondiale di preghiera per il creato. Dostupno na: http://www.vatican.va/content/francesco/it/ messages/pont-messages/2017/documents/papa-francesco_20170901_messaggio-giornata-cura-creato.html (20.3. 2021.); BARTOLOMEJ, Predgovor, 8 .

${ }^{63}$ Messaggio congiunto di papa Francesco e del patriarca ecumenico Bartolomeo per la giornata mondiale di preghiera per il creato. Dostupno na: http://www.vatican.va/content/francesco/it/ messages/pont-messages/2017/documents/papa-francesco_20170901_messaggio-giornata-cura-creato.html (20.3. 2021.). 
melji na zajedničkoj zabrinutosti Pravoslavne i Rimokatoličke Crkve zbog ekoloških ugroza koje prijete čitavom životu na Zemlji.

U tom svom djelu papa Franjo donosi sliku Zemlje kao majke i sestre, pa stoga čitav svijet i sva stvorenja čine obitelj čiji su članovi dužni skrbiti jedni o drugima. ${ }^{64} \mathrm{Papa}$ zbog toga zagovara odgoj za okoliš koji bi se provodio u školama, obiteljima, pomoću sredstava društvenoga priopćavanja, kao i pomoću vjerskih poduka ${ }^{65}$ te poziva na duhovno obraćenje. Duhovno obraćenje jest »ekološko obraćenje «, na koje je već pozivao i papa Ivan Pavao II. ${ }^{66}$

Dok je Bartolomej svoje nadahnuće za odnos prema stvorenom našao u prispodobi o posljednjem sudu, Papa inspiraciju crpi iz Knjige Postanka, a konkretan uzor pronalazi u svetom Franji Asiškom koji je pozivao na poštovanje prema svakom Božjem stvorenju, cijelim svojim životom, te nam je u duhovnoj baštini ostavio Pjesmu stvorova. Dok je Bartolomej povukao paralelu između odnosa Crkve prema okolišu i odnosa Crkve prema siromahu, Papa smatra kako čuvati ljudski život znači čuvati planet $^{67}$ te izričito kaže: $\gg$ Ljudsko dostojanstvo i blagostanje duboko su vezani uz brigu o stvorenome. $\ll{ }^{68}$ Radikalna povezanost svega stvorenoga, u koju Papa vjeruje, traži od čovjeka da se prema svemu stvorenom odnosi s nježnošću, brigom i milosrđem.

$\mathrm{Na}$ tragu ovoga kratkoga prikaza ekumenskoga angažmana čiju okosnicu čine problemi ekološke naravi može se uočiti da su ekološka svijest i briga za očuvanje stvorenoga odgovornost svih te da ekološka nastojanja imaju u sebi i ekumensku dimenziju. U pozadini toga stoji uvjerenje kako je čitava Zemlja, zapravo, jedan veliki zajednički dom.

\section{Zaključak}

Posljednjih desetljeća kod pravoslavnih teologa nalazimo sve veći interes za problematiku očuvanja okoliša. Njihova uporišta ukorijenjena su u bogatoj pravoslavnoj tradiciji, posebice u liturgiji i u asketskoj praksi. U biblijsko-teološkom smislu izvore ekološke odgovornosti teolozi pronalaze i u teologiji stvaranja. Osim toga oni zajedno s katoličkim teolozima otkrivaju ekumensku dimenziju ekoloških pitanja, dapače, u njima vide izazov za ekumenizam. Brojnim teolozima kod ekumensko-ekološke zauzetosti i suočavanja s moralno-ekološkim krizama kao primjeri služe ekumenski patrijarh Bartolomej i papa Franjo. Ta dvojica crkvenih poglavara

\footnotetext{
${ }^{64}$ FRANJO, Naša majka Zemlja, 17-45.

${ }^{65}$ Usp. isto, 35-37.

${ }^{66}$ Usp. isto, 56-60. Papa Ivan Pavao II. to je eksplicitno učinio prigodom kateheze 17. siječnja 2001. Usp. isto, 99.

${ }^{67}$ To je Papa učinio prigodom Plenarne sjednice konferencije FAO-a, 20. studenoga 2014. godine.

${ }^{68}$ FRANJO, Naša majka Zemlja, 81.
} 
u prethodnom desetljeću kroz niz zajedničkih susreta i dijaloga inicirali su brojne projekte ekološke naravi. Potkovani evanđeljima i drugim biblijskim tekstovima, posebice Knjigom Postanka, vjeruju u čovjeka kojemu je povjerena briga i odgovornost za očuvanje okoliša i svega stvorenoga. Međutim oni svjedoče i progovaraju o problemima iskorištavanja prirodnih resursa i svim ostalim ugrozama za prirodu i život, i to za život u svim njegovim oblicima i bogatstvima.

Bez ikakve sumnje može se ustvrditi da je ekologija jedan od izazova u suvremenom svijetu s kojim se čovjek susreće, ${ }^{69}$ a za što je čovjek odgovoran, ${ }^{70}$ a to se očituje i u području teologije, bilo pravoslavne bilo katoličke. Međutim, ipak treba reći da su sva ta nastojanja još uvijek nedovoljna s obzirom na ono što bi čitavo društvo trebalo činiti kako bi još više probudilo svijest o očuvanju prirodnih dobara i ambijenta u kojem živi suvremeni čovjek.

Dok zemlju potresaju brojne krize, među kojima je ekološka tek jedna od gorućih, potrebno je da se u diskurs uključi što više znanstvenih disciplina, ali i onih neznanstvenih i vjerskih perspektiva kako bi se gradio trajan dijalog, pa i onaj ekumenske naravi. Složit ćemo se ovdje s riječima koje je rekao talijanski katolički teolog Pier Giorgio Gianazza: »Nije zadaća Crkve ponuditi političke, socijalne, tehničke solucije koje su stavljene u probleme ekologije. Na nju spada podsjećati čovječanstvo, posebice vlastite vjernike, da cijeli svemir zahtijeva religioznu viziju, ako je povezan s Bogom, koji ga je dao, osim bića i postojanja, također jedan osjećaj, cilj, destinaciju..$^{71} \mathrm{U}$ tom duhu kao dobar podsjetnik može poslužiti misao spomenutoga grčkoga pravoslavnoga teologa Ioannisa Zizioulasa kada kaže kako čovječanstvo ne može ni na koji način preživjeti bez prirodnoga ambijenta niti prirodni ambijent može preživjeti bez čovječanstva. ${ }^{72}$

Unatoč svim teološkim, ekološkim, duhovnim i ekumenskim nastojanjima teolozi, i pravoslavni i katolički, ne mogu donijeti konkretne, materijalne ili tehnološke promjene s obzirom na nastalu ekološku krizu u svijetu. No to im nije ni zadaća. Ono što teolozi i teologija mogu učiniti jest senzibilizirati javnost o ugroženoj zemlji, buditi svijesti o moralnoj odgovornosti za prirodu te izgrađivati novi odnos prema svemu stvorenomu jer odnoseći se dostojanstveno i brižno prema stvorenju, čovjek istodobno štuje Boga stvoritelja.

\footnotetext{
${ }^{69}$ Usp. A. BEKAVAC, F. PODGORELEC, Suvremeni izazovi globaliziranog svijeta. Antropološkoekološka kriza, u: Bogoslovska smotra 84(2014.)2, 349-366.; L. TOMAŠEVIĆ, Ekologija: izazov kršćanstvu, 23-33.

${ }^{70}$ Usp. S. BALOBAN, Suodgovornost za zaštitu čovjekove okoline, u: V. POZAIĆ (ur.), Ekologija: znanstveno-etičko-teološki upiti i obzori, 177-202.

${ }^{71}$ P. G. GIANAZZA, Temi di teologia orientale 2, 41.

${ }^{72}$ Usp. I. ZIZIOULAS, Sacerdoti della creazione, 72.
} 


\title{
THE ORTHODOXY BEFORE CONTEMPORARY ENVIRONMENTAL CHALLENGES WITH SPECIAL EMPHASIS ON THE ECUMENICAL DIALOGUE WITH THE CATHOLIC CHURCH
}

\author{
Antun JAPUNDŽIĆ ${ }^{*}$ - Ana JELIČIĆ́**
}

\begin{abstract}
Summary: Although Orthodox theology has a long and rich tradition, there has been no significant interest in environmental issues recorded in its long history. Namely, it is only in the last few decades that we find environmental preoccupation in the reflections of several Orthodox philosophers and theologians. Their efforts are based on the theology of creation, the ascetic practice, and rich Eastern liturgy. Most notable in Orthodox theology is Ioannis Zizioulas, while significant contributions were also made by Amvrosij Ermakov and Elizabeth Theokritoff, and others. However, there has been a new momentum in expanding the ecological-theological horizon to combat further ecological threats and problems prompted by the dialogical openness of Ecumenical Patriarch Bartholomew and Pope Francis, who recognized ecology as a great challenge for ecumenism.
\end{abstract}

Keywords: ecology, orthodox theology, theology of creation, asceticism, ecological crisis, ecumenism.

\footnotetext{
* Asst. Prof. Antun Japundžić, Ph.D., Catholic Faculty of Theology in Đakovo, Josip Juraj Strossmayer University of Osijek, Petra Preradovića 17, P. O. box 54, 31400 Đakovo, Croatia, antun. japundzic@gmail.com

** Asst. Prof. Ana Jeličić, Ph.D., University Department of Forensic Sciences, University of Split, Ruđera Boškovića 33, 21000 Split, Croatia, anjelici08@gmail.com
} 